Cite this: RSC Advances, 2013, 3, 14329

Received 19th March 2013,

Accepted 15th May 2013

DOI: $10.1039 / \mathrm{c} 3 \mathrm{ra} 41346 \mathrm{~b}$

www.rsc.org/advances

\title{
Correlation of biocapping agents with cytotoxic effects of silver nanoparticles on human tumor cells $\dagger$
}

\author{
Wang Chunyan and Suresh Valiyaveettil*
}

\begin{abstract}
Metal nanoparticles are used in a wide range of commercial products such as cosmetics, food packaging and household detergents. Owing to interesting antimicrobial properties, silver nanoparticles (Ag NPs) are commonly used in many commercial products. Recently, green approaches using plant extracts at room temperature have been developed for the synthesis of Ag NPs. Here we explored a one-pot approach, which combines capping, reducing agents and templates in one bioextract for synthesizing water soluble Ag NPs. Ginger, coffee and mint extracts were used for the synthesis of water soluble Ag NPs. The assynthesized nanostructures were characterized using transmission electron microscopy and UV-Vis spectroscopy. The toxicity of Ag NPs with different capping agents was studied using hepatocellular liver carcinoma cells (HepG2) and human cervical cancer cells (HeLa). The level of toxicity was evaluated using changes in cell morphology, cell viability and oxidative stress studies. Ag NPs caused a decrease in the amount of ATP in cells while plant extracts alone did not have significant effect on the amount of ATP. It is interesting to note that bioextract capped Ag NPs do not increase but decrease production of reactive oxygen species (ROS) in a dose dependent manner, which could mostly be attributed to the antioxidant activity of biocapping agents on the surface of nanoparticles. Ag-mint, Ag-ginger and Ag-coffee NPs treatment caused cell cycle arrest in the G2/M phase and Ag-mint NPs exposure resulted in cell cycle arrest in the sub G1 stage. Annexin-V propidium iodide staining showed a large amount of apoptosis in Ag-mint NPs treated cells. A possible mechanism of toxicity of Ag NPs resulted from interruption of ATP synthesis, which further caused DNA damage and cell death through apoptosis. A complete elimination of toxicity, especially at higher concentrations of Ag NPs has not yet been achieved.
\end{abstract}

\section{Introduction}

Nanotechnology is being explored in a wide range of applications in different communities ranging from military, industrial, and medical to academic laboratories. ${ }^{1-3}$ Compared to their bulk counterparts, nanomaterials have unique chemical, optical, mechanical, electronic and magnetic properties, which enable them to have many potential applications in wide areas of medicine, energy, environment and consumer goods. ${ }^{4,5}$ Metallic nanoparticles (NPs) have been used for several biomedical applications for the last 20 years. $^{6}$ An organic capping agent with functional groups is used to finetune solubility, stability, surface charges, and interactions of NPs with other molecules. The nature of the capping agent influences both the physical properties and biological properties of NPs. ${ }^{7-11}$ Recently, there has been growing interest in developing environmentally friendly and multifunctional biomaterials as capping agents for nanoparticles to reduce toxicity. ${ }^{12-17}$

Department of Chemistry, Faculty of Science, 3 Science Drive 3, National University of Singapore, Singapore 117543.E-mail: chmsv@nus.edu.sg

$\dagger$ Electronic supplementary information (ESI) available. See DOI: 10.1039/ c3ra41346b
Owing to their antimicrobial activity, Ag NPs have been used in a wide range of consumer products ranging from cosmetics to household products and medical applications including imaging, drug delivery and disinfection. Ag NPs impregnated catheters ${ }^{18}$ and wound dressings ${ }^{19}$ are used in therapeutic applications. However, previous studies have indicated that nanoparticles have a size-, time- and dosedependent cytotoxicity, where smaller particles with longer exposure time at higher concentrations showed the highest toxicity. ${ }^{9,20}$ A possible mechanism of cytotoxicity of Ag NPs involves disruption of the mitochondrial respiratory chain, increase of ROS production and interruption of ATP synthesis, which in turn cause DNA damage. ${ }^{20}$ To the best of our knowledge, little is known about the influence of capping agents on the bioactivity of Ag NPs. ${ }^{21,22}$

Green approaches have been employed for the synthesis of NPs in which plant extracts were used as reducing agents and capping agents. ${ }^{23-27}$ Here we use common ginger, ${ }^{28}$ mint and coffee $^{29}$ extracts as reducing and capping agents to control the size and surface functional groups for the synthesis of water soluble Ag NPs. In addition, the bioextracts may also affect the toxicity of the Ag NPs. The characterization of Ag NPs was done using UV-Vis and TEM and the effects of exposure time and 
dosage affecting cellular uptake and cytotoxicity of the prepared Ag NPs in human cancer HeLa and HepG2 cells were studied.

\section{Experimental}

\section{Materials}

Silver nanoparticle synthesis was carried out using a standard procedure through the reduction of silver nitrate. ${ }^{30}$ All glassware used for the synthesis was treated with piranha solution (30\% hydrogen peroxide/concentrated sulphuric acid in $3: 1$ ratio) and washed thoroughly in ultrapure water (Millipore Corporation). Dry mint leaves and ginger rhizome were purchased from local Chinese traditional medicine shops, while pure soluble coffee (Nescafe Gold), 100\% freezedried soluble coffee (Nestle Korea Ltd.) was purchased from a local supermarket in Singapore. Silver nitrate (99\%) was purchased from Sigma-Aldrich.

The selection of these extracts as reducing agents and capping agents was based on enhancing the solubility and stability of Ag NPs in the cell culture medium. All extracts reduced silver nitrate to $\mathrm{Ag}$ NPs at room temperature without the need for other reducing agents. ${ }^{22,23} \mathrm{Ag}$ NPs showed high dispersion and solubility at high concentrations during the cell viability studies.

\section{Synthesis of Ag NPs}

Dried mint leaves $(5 \mathrm{~g})$ were washed 3 times with $200 \mathrm{~mL}$ Millipore water before boiling in $350 \mathrm{~mL}$ water until the volume was reduced to $150 \mathrm{~mL}$, and the final solution was filtered with filter paper. The extract was kept in a $-20{ }^{\circ} \mathrm{C}$ fridge overnight before freeze drying to obtain a dry powder. No attempt was made to purify or isolate compounds in the extracts. Finally, the appropriate amount of mint extract powder was weighed and dissolved in Millipore water to obtain a standard mint extract solution. Ag NPs were synthesized by reducing silver nitrate solution with mint extract solution at the ratio $m_{\mathrm{Ag}} / m_{\operatorname{mint}}=1 / 5$ under constant stirring at room temperature. The color of the solution changed to yellowish brown with time (Fig. 1), indicating nanoparticle formation. The mixture was stirred for an additional $2 \mathrm{~h}$. Ag NPs were purified using repeated centrifuging and washing with water to remove any traces of unbound
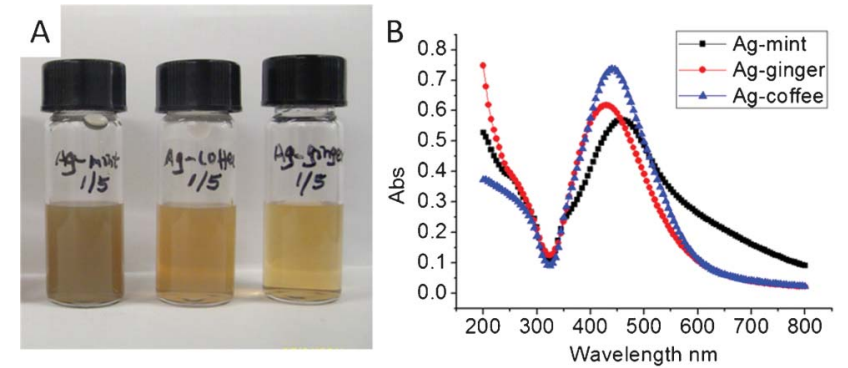

Fig. 1 Optical images (A) and UV-Vis spectra (B) of Ag-mint, Ag-coffee and Agginger NPs solutions. The concentration of the solution in $(A)$ is $0.1 \mathrm{mg} \mathrm{mL}^{-1}$. mint extracts, dispersed in pure water and used for structural characterization.

Ginger extract was generated from dried ginger rhizome following the above procedures while pure soluble coffee (Nescafe Gold) was used directly for the coffee extract. Agginger and Ag-coffee NPs were synthesized as described above for the Ag-mint NPs.

\section{Characterization of Ag NPs}

The morphology of the Ag-mint, $\mathrm{Ag}$-coffee and Ag-ginger NPs was observed with a JEOL 2010-F Field Emission Transmission Electron Microscope (FETEM). Briefly, an aqueous solution of Ag NPs $(10 \mu \mathrm{L})$ was dropped onto the copper grids and left to dry in air. Then the samples were imaged using TEM. Dynamic light scattering (DLS) and zeta potential measurements of the $\mathrm{Ag}$ NPs aqueous solution were performed using a Malvern Zetasizer Nano-ZS90 at room temperature. The absorption spectrum of the Ag NPs was measured using a UV-Vis spectrophotometer (Shimadzu UV-1601PC). Elemental analysis of the freeze-dried Ag-mint, Ag-ginger and Ag-coffee NPs was performed for their respective elemental compositions. The presence of carbon, hydrogen and nitrogen was detected using an Elementar Vario Micro Cube. Inductively-coupled plasma (ICP) analysis (Dual-view Optima 5300 DV ICP-OES) was used for the determination of the silver level in the digested solutions of Ag NPs.

\section{Cell culture}

HeLa and HepG2 cells were purchased from commercial sources, American Type Culture Collection, USA. Cells were maintained in Dulbecco's modified eagles medium (DMEM, HyClone) supplemented with $10 \%$ fetal bovine serum (FBS, GIBCO) and $1 \%$ penicillin streptomycin (Gibco, Invitrogen). Cells were maintained in a $5 \% \mathrm{CO}_{2}$ incubator at $37{ }^{\circ} \mathrm{C}$.

\section{CytoViva optical microscopy}

Morphology observations of the cells treated with extracts alone were performed on HepG2 cells, which were cultured in a 24-well plate (Griener Bio-one $\mathrm{GmbH}$ ) with one sterilized microscope cover glass (Marlenfeld $\mathrm{GmbH}$ ) laid at the bottom of the well. The cover glass was soaked with $70 \%$ ethanol for 2 min and washed with sterile phosphate buffered saline (PBS, Vivantis) twice before the addition of 6000 cells with $1 \mathrm{~mL}$ of media into each well with overnight incubation at $37{ }^{\circ} \mathrm{C}$ in a $5 \% \mathrm{CO}_{2}$ atmosphere. Spent media was removed the next day and replaced with fresh media along with mint, ginger or coffee extracts $\left(20 \mu \mathrm{g} \mathrm{mL}^{-1}\right)$. Control cells were grown under identical conditions in medium only. The cover glasses were removed from the wells after $24 \mathrm{~h}$ and rinsed with sterile PBS before placing face-down onto a clean glass slide for observation. Changes in the morphology of HepG2 and HeLa cells treated with Ag NPs $\left(20 \mu \mathrm{g} \mathrm{mL}{ }^{-1}\right)$ with different capping agents were checked with a similar procedure to that described above.

\section{Cell viability assay}

The viability of cells treated with Ag-mint, Ag-coffee and Agginger NPs was measured using a CellTiter-Glo luminescent cell viability assay (Promega) following the manufacturer's 
instructions. This assay determines the number of viable cells in a cell culture based on quantification of the adenosine5 '-triphosphate (ATP) present, which signals the presence of metabolically active cells. ${ }^{31}$ The assay is based on the conversion of luciferin to oxyluciferin by a recombinant luciferase in the presence of ATP. The observed luminescence is proportional to the quantity of ATP in the cells.

The experiments were performed in 96-well plates (Corning, Costar). For the ATP assay, 3000 cells were plated in each well and incubated in $100 \mu \mathrm{L}$ of media overnight for the cells to adhere to the bottom of the well. Spent media was removed the next day and replaced with fresh media and the cells were treated with different concentrations of Ag NPs $(0,10,25,50$ and $100 \mu \mathrm{g} \mathrm{mL} \mathrm{m}^{-1}$ ) for 24,48 , and $72 \mathrm{~h}$. At certain time points, $100 \mu \mathrm{L}$ of CellTiter-Glo viability assay pre-warmed to room temperature was added into each well and mixed properly. After $15 \mathrm{~min}$, luminescence readings were measured using a Tecan Infinite F200 micro-plate reader.

The dependence of toxicity on Ag NPs was studied using mint, ginger and coffee extract stock solutions. Cells were treated with mint, ginger and coffee extracts $\left(100 \mu \mathrm{g} \mathrm{mL}^{-1}\right)$ in 96-well plates for different incubation periods $(24 \mathrm{~h}, 48 \mathrm{~h}$ and $72 \mathrm{~h})$.

\section{Detection of reactive oxygen species (ROS) production}

The generation of ROS was evaluated by employing $2^{\prime}, 7^{\prime}$-dichlorodihydrofluorescein diacetate (DCF-DA, Invitrogen) staining. ${ }^{32,33}$ In the presence of $\mathrm{H}_{2} \mathrm{O}_{2}$ or hydroxyl radicals, DCF-DA is converted to highly fluorescent $2^{\prime}, 7^{\prime}$-dichlorodihydrofluorescein (DCF). The ROS assay was performed using the supplier's instructions. Approximately 5000 cells incubated with $\mathrm{Ag}$ NPs $(0,10,25,50$, and $100 \mu \mathrm{g}$ $\mathrm{mL}^{-1}$ ) for $24 \mathrm{~h}$ in a 96-well plate were washed with PBS twice and incubated with $10 \mu \mathrm{M}$ DCF-DA for $30 \mathrm{~min}$ at $37{ }^{\circ} \mathrm{C}$ in the dark. Then the cells were washed twice with PBS and analyzed by a microplate reader (BioTek, Synergy 4) at an excitation wavelength of $485 \mathrm{~nm}$ and an emission wavelength of 530 $\mathrm{nm} .^{34}$

\section{Annexin-V staining}

Annexin-V staining was performed to determine apoptotic and necrotic cell death induced by Ag NPs. Annexin-V, a family of calcium-dependent phospholipid-binding proteins, has a high affinity for phosphotidyl serine (PS). Upon initiation of apoptosis, PS is translocated from the inner to the outer leaflet of the plasma membrane, thus exposing PS to the external cellular environment. Use of propidium iodide (PI) staining helps to differentiate between apoptosis and necrosis, which is attributed to the difference in permeability of PI through the cell membranes of live and damaged cells. Approximately $2.5 \times 10^{5}$ HepG2 and HeLa cells were placed in a $60 \times 15 \mathrm{~mm}$ tissue culture dish (Falcon, Franklin Lakes), and then treated with Ag NPs $\left(20 \mu \mathrm{g} \mathrm{mL}^{-1}\right)$ for $24 \mathrm{~h}$. Treated cells were harvested and washed twice in Dulbecco's phosphate buffered saline (DPBS, Sigma-Aldrich) and stained (annexin-V FITC apoptosis detection kit, Sigma-Aldrich) as in the manufacturer's instructions before detection with flow cytometry (Epics Altra, Beckman and Coulter). Data was collected for $1 \times 10^{4}$ gated cells and analyzed using Summit V4.3.02 software.

\section{Cell cycle analysis}

Cell cycle analysis was performed by staining DNA with propidium iodide (PI, Sigma-Aldrich). Cell numbers, concentrations, and culture conditions were similar to the annexin-V analysis. Following treatment of cells with the Ag NPs for $24 \mathrm{~h}$, the cell medium was removed and stored. The cells were washed in PBS, trypsinized, harvested in the stored medium, and centrifuged. The pellet was washed twice in PBS, fixed in freshly prepared ice-cold ethanol (70\%), and stored at $-20{ }^{\circ} \mathrm{C}$ overnight. Thereafter, the cells were washed in PBS, and stained with PI in RNase $\left(40 \mu \mathrm{g} \mathrm{mL}^{-1} \mathrm{PI}\right.$ and $100 \mu \mathrm{g} \mathrm{mL} \mathrm{mL}^{-1}$ RNase A) at $37{ }^{\circ} \mathrm{C}$ for $30 \mathrm{~min}$, followed by incubation at $4{ }^{\circ} \mathrm{C}$ until analysis. Flow cytometry analysis was performed at an excitation wavelength of $488 \mathrm{~nm}$ and emission wavelength of $610 \mathrm{~nm}$ (Epics Altra, Beckman and Coulter). Data collected for $1 \times 10^{4}$ cells for HepG2 cells and HeLa cells was analyzed using Summit V4.3.02 software.

\section{Statistical analysis}

Statistical analyses of data for all experiments are expressed as means and standard deviations. The data were analyzed using Student's $t$-test (Microsoft Excel, Microscoft Corporation). Differences were considered as statistically significant when the $P$ value was $<0.05$.

\section{Results and discussion}

The separation and identification of various components in coffee, ginger and mint extracts have been reported in the literature. ${ }^{28,29,35-41}$ The extracts from the above materials contain polyphenols, ${ }^{42-44}$ which can form complexes with silver ions in solution and reduce them to $\mathrm{Ag}$ NPs. ${ }^{23}$ Some other compounds existing in the extracts may also help to stabilize the Ag NPs in solution, which include caffeine, sucrose and amino acids in coffee extract, ${ }^{45}$ and ascorbic acid in both ginger and mint extracts. ${ }^{40,46}$ All Ag NPs capped with plant extracts were synthesized at room temperature, and purified by repeated centrifuging and washing. These Ag NPs were stable at room temperature for long periods of 6 months or more. Ag-mint, $\mathrm{Ag}$-ginger and $\mathrm{Ag}$-coffee NPs showed good solubility in water with bluish yellow, brownish yellow and light brownish yellow colors, respectively (Fig. 1A). From the elemental analysis of the lyophilized particles, it appears that Ag-mint had a slightly higher Ag content (48.76 wt\%) than Agginger (41.33 wt\%) and Ag-coffee (41.46 wt\%). Ag NPs exhibit unique surface plasmon resonance (SPR) properties which could be detected by UV-Vis spectroscopy (Fig. 1B); a characteristic absorbance band of Ag NPs is dependent on the size of the nanoparticles. Ag-mint NPs showed a maximum absorbance at $460 \mathrm{~nm}$, while $\mathrm{Ag}$-coffee NPs and $\mathrm{Ag}$-ginger NPs showed absorption maxima at $442 \mathrm{~nm}$ and 424 $\mathrm{nm}$, respectively (Table 1 ). 
Table 1 Chemical composition (in wt\%), DLS results, zeta potentials and SPR peaks of Ag-mint, Ag-coffee and Ag-ginger NPs

\begin{tabular}{|c|c|c|c|c|c|c|c|c|}
\hline Element & $\mathrm{Ag}$ & $\mathrm{C}$ & $\mathrm{H}$ & $\mathrm{N}$ & O (estimate) & $Z$-average (nm) & Zeta potential $(\mathrm{mV})$ & SPR peak $(\mathrm{nm})$ \\
\hline $\mathrm{Ag}-$ mint NPs & 48.76 & 10.45 & 1.45 & 2.38 & 36.96 & 97 & -10.1 & 460 \\
\hline Ag-coffee NPs & 41.46 & 37.04 & 3.23 & 5.63 & 12.64 & 54 & -27.1 & 442 \\
\hline Ag-ginger NPs & 41.33 & 19.31 & 3.35 & 5.43 & 30.58 & 118 & -10.2 & 424 \\
\hline
\end{tabular}

\section{TEM analysis of Ag NPs}

TEM images show that Ag NPs of varying size were formed using different natural material extracts (Fig. 2A-C). For Agmint NPs, the size distribution was in the range of 5 to10 $\mathrm{nm}$ with a few larger NPs with sizes of $50 \mathrm{~nm}$ (Fig. 2A); for $\mathrm{Ag}$ ginger NPs, the NPs were distributed in the range of 5 to 10 along with some large particles ranging from 30 to $40 \mathrm{~nm}$ (Fig. 2B); while for Ag-coffee NPs, the size of Ag NPs was much larger and more uniform, with the majority in the range of 30 to $40 \mathrm{~nm}$ (Fig. 2C). The calculated size distribution histograms are shown in Fig. 2D-F.

The size of Ag NPs depends on the efficiency of the reducing agent and the binding ability of the capping agent. Smaller Ag NPs could be obtained through slow reduction, ${ }^{47}$ or in the presence of a strong capping agent. ${ }^{48}$ In our experiment, mint, ginger and coffee extracts were used as both reducing agents and capping agents. Among the three Ag NPs prepared under similar conditions, Ag-mint NPs were smaller while Ag-coffee NPs were much larger (Fig. 2), indicating that the mint extracts were more active towards reduction of $\mathrm{Ag}^{+}$ions and capping the nanoparticles.

\section{DLS and zeta potential measurements}

The hydrodynamic diameters of the Ag NPs were determined using a Malvern Zetasizer Nano System. All Ag NPs are dispersible in water owing to the hydrophilic capping agents which can prevent individual particles from aggregating. As can be seen in Table 1, DLS measurements showed that the mean hydrodynamic diameters were $97 \mathrm{~nm}, 118 \mathrm{~nm}$ and 54 $\mathrm{nm}$ for Ag-mint, Ag-ginger and Ag-coffee, respectively. TEM images give the diameters of the NPs in the dry state, while DLS offers the hydrodynamic size distribution which includes the core particle, its organic layers (capping agents) and the hydration shell. ${ }^{49}$ The zeta potential values of $\mathrm{Ag}$-mint and $\mathrm{Ag}$ ginger NPs were $-10.1 \mathrm{mV}$ and $-10.2 \mathrm{mV}$ while that of $\mathrm{Ag}-$ coffee NPs was $-27.1 \mathrm{mV}$ (Table 1 ). The high negative charge of the Ag-coffee NPs could enhance the stabilization, which led to smaller hydrodynamic diameters compared to the other two NPs.

\section{Elemental analysis}

As can be seen in Table 1, it is apparent that the ratio of capping agent to silver in Ag-coffee was high. On the contrary, the lowest carbon content was observed for Ag-mint NPs. The silver content $(48.8 \%, 41.3 \%$ and $41.5 \%)$ of all three samples were comparable which enables a fair comparison between these three NPs in cell viability testing. The oxygen content of the Ag-mint NPs was found to be higher than expected due to its hygroscopic nature.

\section{Dark field microscopy}

The first readily noticeable effect seen after exposure of cells to toxic materials is the alteration in cell shape or morphology. The experiment was first performed by treating HepG2 cells

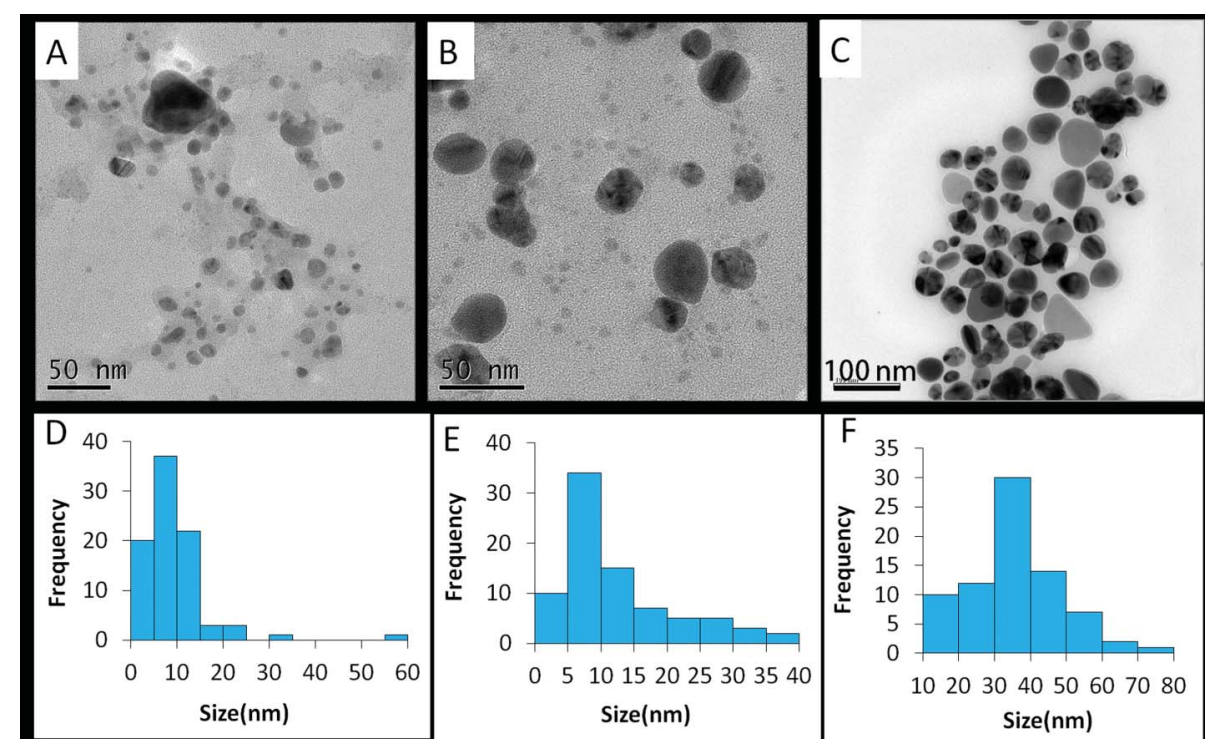

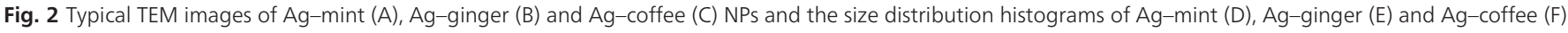
generated using images (A-C) captured with a JEOL JSM $2010 \mathrm{~F}$. 

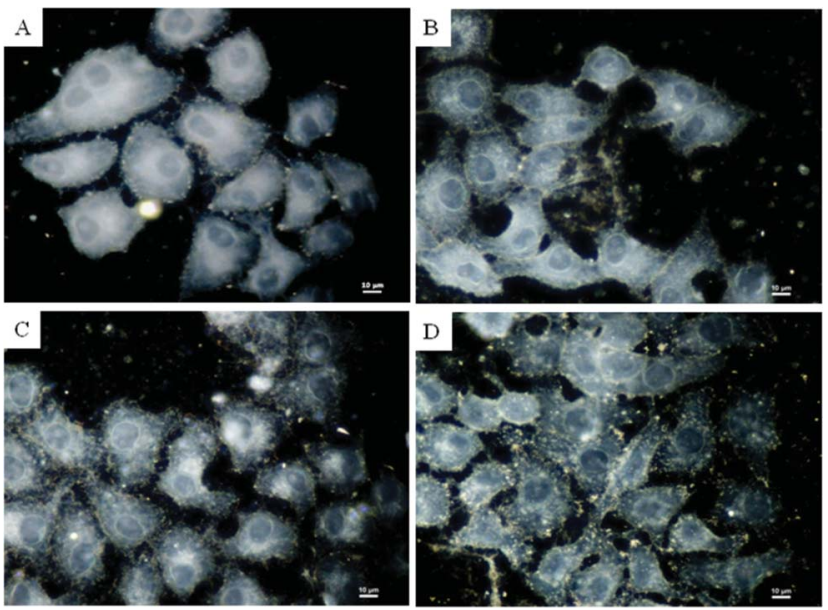

Fig. 3 Optical images of HepG2 cells untreated (A) and treated with mint extracts (B), coffee extracts (C) and ginger extracts (D). Concentration of extracts $=20 \mu \mathrm{g} \mathrm{mL}$

with mint, coffee and ginger extracts alone for $24 \mathrm{~h}$ and comparing them with the untreated cells which served as a control. As can be seen in Fig. 3, the plasma membrane, nuclear envelopes, cellular contents and organelles of all the cells could be observed in dark field microscopy. However, untreated cells showed much clearer plasma membranes compared to those treated with mint, coffee and ginger extracts which become less distinct from each other, although they still appeared to maintain their structural integrity as the membranes remained intact.

The morphology changes of the HepG2 cells treated with Ag NPs $\left(20 \mu \mathrm{g} \mathrm{mL}{ }^{-1}, 24 \mathrm{~h}\right)$ were also compared with the untreated cells (Fig. 4). Images of the treated cells showed distinct morphological changes indicating unhealthy cells, whereas the control cells appeared normal. Ag-mint NPs treated cells appeared to be slightly elongated as compared to the untreated cells. This could be due to the disturbances in the cytoskeletal framework as a consequence of the nanoparticle treatment. Untreated cells showed a small number of bright, roundshaped spots distributed throughout the cells. These bright specks (green arrows) could be transport vesicles (endosomes) or organelles which contain high concentrations of ions and proteins (Fig. 4A). Such bright specks should not be mistaken for Ag NP aggregates (yellow arrows) which are randomlyshaped. Ag NPs are so small that they could not be observed directly under an optical microscope. Therefore, the bright objects seen in these images should be considered as scattered light from nanoparticles. It is also clearly found that Ag NPs entered the cytoplasm but not the nucleus, which is consistent with findings in the literature. ${ }^{50} \mathrm{Ag}$-mint treated cells showed more sparkling specks with visible cell morphology changes indicating that they could penetrate the cell membrane more efficiently (Fig. 4B) owing to their smaller size. In contrast, cells treated with Ag-coffee NPs and Ag-ginger NPs showed no morphology changes along with sparking specks inside the cells (Fig. 4C and 4D) which can be interpreted that such Ag NPs are less toxic than Ag-mint NPs. Similar results were also observed for Ag NPs treated HeLa cells (Fig. S1, ESI $\dagger$ ). Many
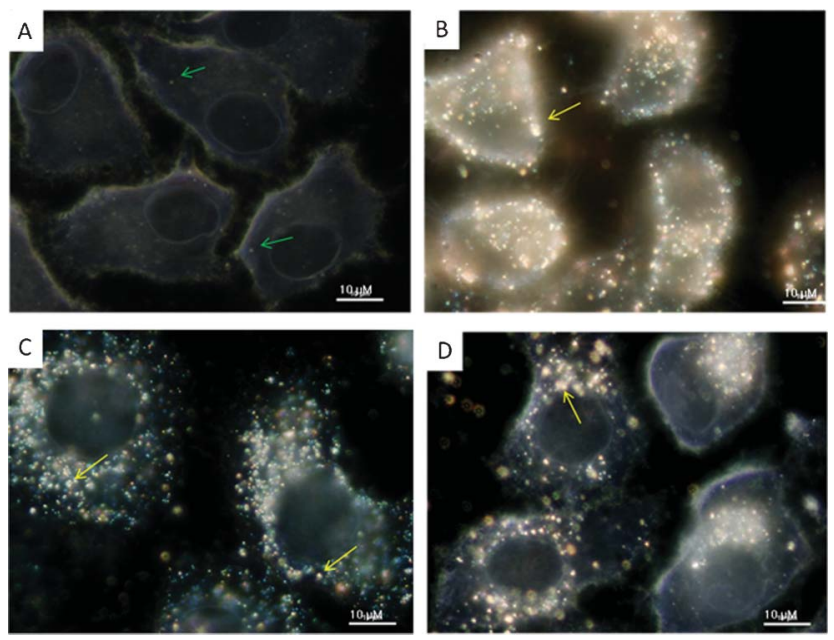

Fig. 4 Optical images of HepG2 cells untreated (A) and treated with Ag-mint (B), Ag-coffee (C) and Ag-ginger (D) NPs. Concentration of Ag NPs $=20 \mu \mathrm{g}$ $\mathrm{mL}^{-1}$. Green arrows point to cellular components such as endosomes and lysosomes, while yellow arrows point to big Ag NPs aggregates.

papers from different laboratories have reported that uptake of nanoparticles is size-dependent. ${ }^{9,33,51}$ It has been shown that the optimal nanoparticle radius for endocytosis is in the order of $25-30 \mathrm{~nm} .{ }^{51}$ Smaller particles $(<10 \mathrm{~nm})$ are known to pass through various pores in the cell membrane. The cellular uptake of nanoparticles was also dependent on the nature of the capping agent. ${ }^{7}$ Generally, the smaller water soluble nanoparticles with targeting groups (e.g. transferrin, folic acid, galactose) are absorbed faster into the cell as compared to those capped with nontargeting capping agents such as PVP and PEG. ${ }^{52-54}$ The dark field images also show that Au NPs could be selectively delivered into the cell nucleus by using RGD (arginine-glycine-aspartic acid) and nuclear location sequence (NLS) peptides or the cytoplasm region using RGD alone, while the PEG conjugated Au NPs did not enter into the cells. ${ }^{55}$ Further the cellular uptake of nanoparticles was also dependent on the cell lines. ${ }^{56}$ Recently, we reported that platinum nanoparticles capped with PVP showed higher cellular uptake in HeLa cells than in MCF7 and IMR90 cells. ${ }^{54}$ The strong reflection from Ag NPs observed in our study could be attributed to many factors, such as size or capping agents. Moreover, similar results were also found in Ag NPs capped with tea extract. ${ }^{21} \mathrm{Ag}$ NPs capped with epicatechin alone showed minimal interaction with human keratinocyte cells (HaCaT) while Ag NPs capped with tea extract showed extensive interaction (at the $1: 1$ ratio of water to tea extract). ${ }^{21}$ Furthermore, the interaction between cells with Ag NPs decreased with a decreasing concentration of tea extract.

\section{Viability assay}

Viability assays are important for identifying toxicity that indicates the cellular response to a toxic chemical and gives information on cell death, survival and metabolic activities. A concentration- and time-dependent study was performed to find out the effect of Ag NPs on cell viability. Commonly used viability assays such as MTT or MTS assay were used to study 
the viability and the proliferation of cells through monitoring the absorbance of a formazan product formed in living cells. However, nanomaterials which show similar optical properties to a formazan product caused errors during the quantitative analysis. In our experiments, Ag NPs solution which showed distinct UV-Vis absorption peaks gave inaccurate results when MTT or MTS assays were used. Such absorbance-based methods are considered not suitable for Ag NPs treated cells. The Cell Titer-Glo luminescent cell viability assay was used in our experiment which could monitor cytotoxicity as well as cell proliferation. This assay measures the amount of ATP present in the culture medium, which is proportional to the number of viable cells. It is more sensitive with short waiting times (minutes) compared to other assays such as resazurin assay and MTS (1 to $4 \mathrm{~h}$ or more). ${ }^{57}$

The viability trends of $\mathrm{Ag}$-mint, $\mathrm{Ag}$-ginger and $\mathrm{Ag}$-coffee treated cells were similar across different cell types. Generally, the viability of cells decreased with an increase in the concentration of Ag NPs and with exposure time from $24 \mathrm{~h}$ to $72 \mathrm{~h}$ (Fig. 5). HepG2 cells showed high ATP content (>70\%) when treated with all three Ag NPs at a lower dosage $(10 \mu \mathrm{g}$ $\mathrm{mL}^{-1}$ ), however, the ATP level decreased more significantly for cells treated with higher concentrations of Ag-mint NPs than the others. HepG2 cells treated with Ag-mint NPs showed low ATP content ( $20 \%$ or even less) at the dosage $25 \mu \mathrm{g} \mathrm{mL} \mathrm{m}^{-1}$ or higher. Ag-ginger treated cells showed ATP depletion of close to 0 at a concentration of $50 \mu \mathrm{g} \mathrm{mL} \mathrm{m}^{-1}$ or higher. However, for cells treated with Ag-coffee NPs, ATP was nearly 50\% and 30\% at concentrations of $50 \mu \mathrm{g} \mathrm{mL} \mathrm{m}^{-1}$ and $100 \mu \mathrm{g} \mathrm{mL} \mathrm{m}^{-1}$, respectively. This observation suggests that among all the

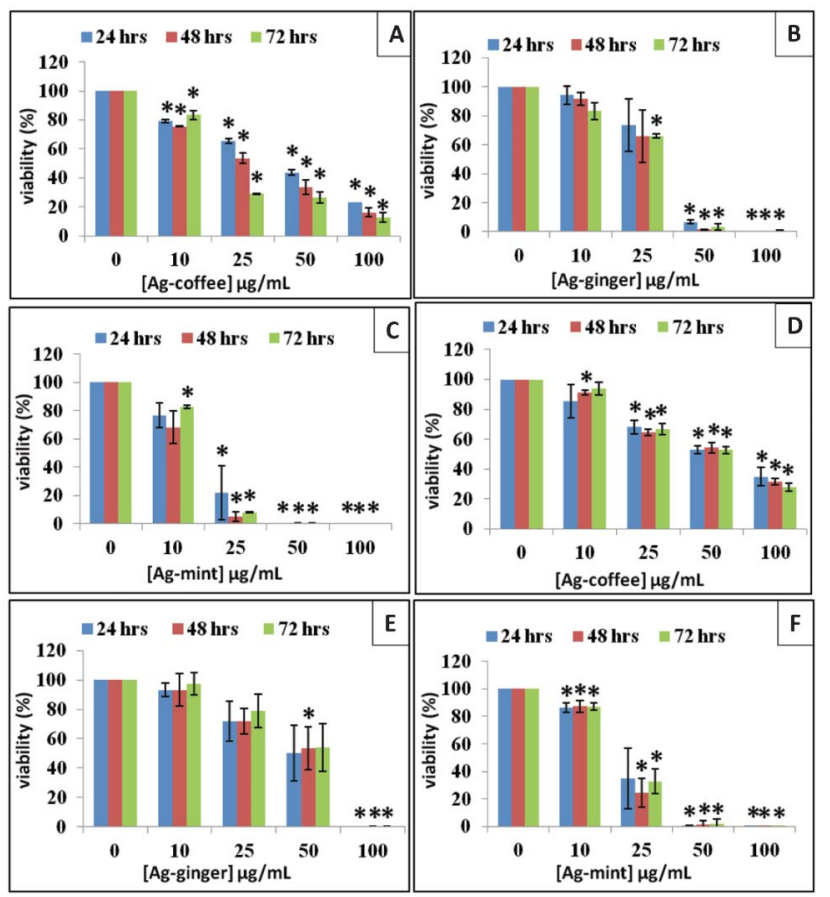

Fig. 5 Viability of HepG2 cells treated with Ag-coffee NPs (A), Ag-ginger NPs (B), Ag-mint NPs (C) and HeLa cells treated with Ag-coffee NPs (D), Ag-ginger NPs (E), Ag-mint NPs (F) at different concentrations; * represents $P<0.05$.

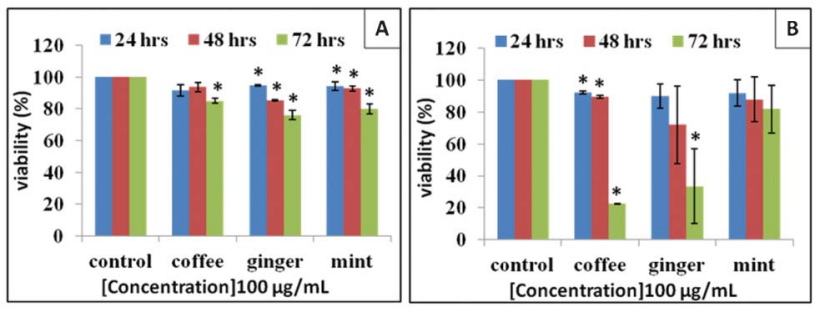

Fig. 6 Comparison of viability of HepG2 (A) and HeLa (B) cells treated with coffee, ginger and mint extracts $\left(100 \mu \mathrm{g} \mathrm{mL}^{-1}\right)$; ${ }^{*}$ represents $P<0.05$.

three NPs screened, Ag-mint NPs were found to be the most toxic, followed by Ag-ginger NPs, and Ag-coffee NPs showed the least toxicity. Compared to HepG2 cells, HeLa cells treated with Ag NPs seem to have higher viability at the same concentration, indicating that Ag NPs showed different toxicity to different cell lines. The cytotoxicity of Ag NPs with different capping agents was also explored on human normal cell line: human dermal fibroblast (HDF, Gibco, Life Technologies) cells (Fig. S2, ESI $\dagger$ ). Similar results were also observed in HDF cells. After exposure to $\mathrm{Ag}$ NPs for $24 \mathrm{~h}$, the toxicity of all three $\mathrm{Ag}$ NPs to the cells was dependent on the dose. Furthermore, of all three Ag NPs, Ag-mint NPs were the most toxic, followed by $\mathrm{Ag}$-ginger NPs and then Ag-coffee NPs. All the data put together suggest that a change in the capping agent of the Ag NPs not only changes the extent of toxicity in human cancer cells but also in normal cells. When natural material extracts alone were used as a control, they showed no significant cytotoxicity in HepG2 cells even at high concentrations (100 $\mu \mathrm{g}$ $\mathrm{mL}^{-1}$, Fig. 6A). However, coffee and ginger extracts were more toxic to HeLa cells at $72 \mathrm{~h}$ (Fig. 6B). A low ATP value does not always represent cell death and it could be due to the inhibition of metabolic processes in the cells. No significant cell death was observed in the presence of Ag NPs at low concentrations. The absence of a large number of floating cells in the culture medium implies a possibility of metabolic arrest. Hence, it is of great importance to analyze the cell cycle to interpret the viability data fully.

\section{Detection of ROS production}

Oxidative stress was reported to play an important role in nanoparticle toxicity. ${ }^{58}$ It is known that a small size and large surface area of nanoparticles could generate ROS. Oxidative stress represents an imbalance between the production and manifestation of ROS, which has specific effects in the cells such as oxidative damage to protein, lipids and DNA. ${ }^{59}$ All three extracts used in our experiments were reported to have antioxidant components. ${ }^{39,60,61}$ The antioxidant components of the coffee extracts were polyphenols and melanoidins. ${ }^{62}$ The major constituents of mint leaf extract include terpenes $(\alpha$-menthol, neomenthol) and flavonoids (quercetin, eugenol) ${ }^{63}$ Similarly, the ginger extracts contain gingerols, shogaols and some related phenolic ketone derivatives. ${ }^{60}$ Ginger extracts are reported to possess antioxidant characteristics and known to scavenge superoxide anion and hydroxyl radicals. ${ }^{64}$ To check the effect of capping agents on the surface of Ag NPs in the production of ROS, DCF-DA staining methods 


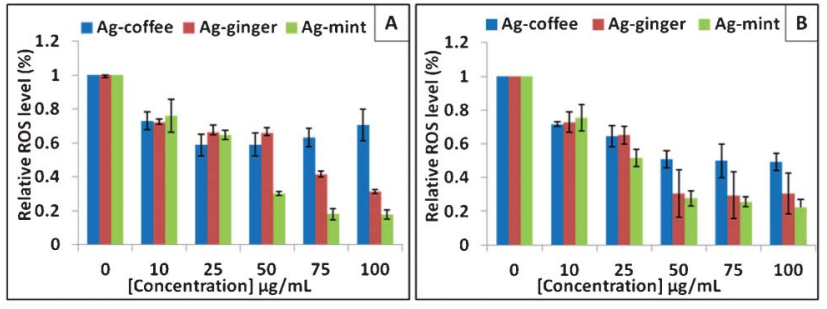

Fig. 7 ROS production from DCF-DA staining of HepG2 (A) and HeLa (B) cells treated with Ag-coffee NPs, Ag-ginger NPs and Ag-mint NPs for $24 \mathrm{~h}$. Untreated cells were a negative control. All the data are significantly different from the control, as all the $P$ values are $<0.05$.

were conducted in HepG2 and HeLa cells. In the presence of ROS, DCF-DA is promptly oxidized to $2^{\prime}, 7^{\prime}$-dichlorodihydrofluorescein (DCF), which is highly fluorescent. ${ }^{20}$ However, no significant increase was observed when cells were treated with different Ag NPs (Fig. 7). On the contrary, the analysis showed a decrease of ROS in both cell lines, which is proportional to concentration of Ag NPs. Even at a low concentration of $10 \mu \mathrm{g}$ $\mathrm{mL}^{-1}$, the ROS level was less than $20 \%$ as compared to the control cells for all three Ag NPs. For Ag-mint and $\mathrm{Ag}$-ginger treated cells, the ROS level decreased drastically as the concentration of NPs increased. For Ag-mint NPs (100 $\mu \mathrm{g}$ $\mathrm{mL}^{-1}$ ) treated cells, the ROS concentration of HepG2 cells was less than $20 \%$ while $30 \%$ of ROS was observed in HeLa cells. For Ag-ginger NPs $\left(100 \mu \mathrm{g} \mathrm{mL} \mathrm{mL}^{-1}\right)$ treated cells, an approximately $60 \%$ reduction of ROS was observed in both cell lines. The ROS data shows that Ag-mint NPs had the highest antioxidant capacity, followed by Ag-ginger NPs. ROS production was reported to be dependent on the nanoparticle surface functionalization. ${ }^{65} \mathrm{Ag}$ NPs with other capping agents such as PVP, starch, citrate or tannic acid were reported to induce cytotoxicity through ROS production. ${ }^{20,66-69}$ The decreased ROS in cells treated with our Ag NPs could be attributed to the antioxidant effect of the capping agents.

\section{Mechanism of toxicity}

The differences in toxicity of $\mathrm{Ag}$-mint, $\mathrm{Ag}$-ginger and $\mathrm{Ag}$ coffee NPs could be due to many factors such as size of nanoparticles, silver content and nature of capping agent. Small nanoparticles showed high toxicity due to enhanced uptake into the cells and large surface area for interaction with biological molecules ${ }^{70}$ or generation of ROS. ${ }^{71}$ The majority of $\mathrm{Ag}$-mint and $\mathrm{Ag}$-ginger NPs were in the range of 5 to $10 \mathrm{~nm}$ while $\mathrm{Ag}$-coffee NPs were in the range of 30 to $40 \mathrm{~nm}$. The silver content of $\mathrm{Ag}$-mint was higher (49\%) compared to that in $\mathrm{Ag}$-coffee (42\%) and $\mathrm{Ag}$-ginger (41\%). Under slightly acidic conditions, $\mathrm{Ag}^{\mathrm{O}}$ can be converted to $\mathrm{Ag}^{+}$, which is believed to be responsible for ROS production and the cause of the cell damage. ${ }^{66,68}$

ROS was reported to have the potential to inhibit or promote cell proliferation by modulating the cell signaling pathways. ${ }^{72}$ ROS is produced in response to a variety of extracellular and intracellular stimuli, whose reactivity and regulation could be controlled by antioxidants. ${ }^{73}$ Zhang et al. have reported that apoferritin-encapsulated platinum nanoparticles can improve

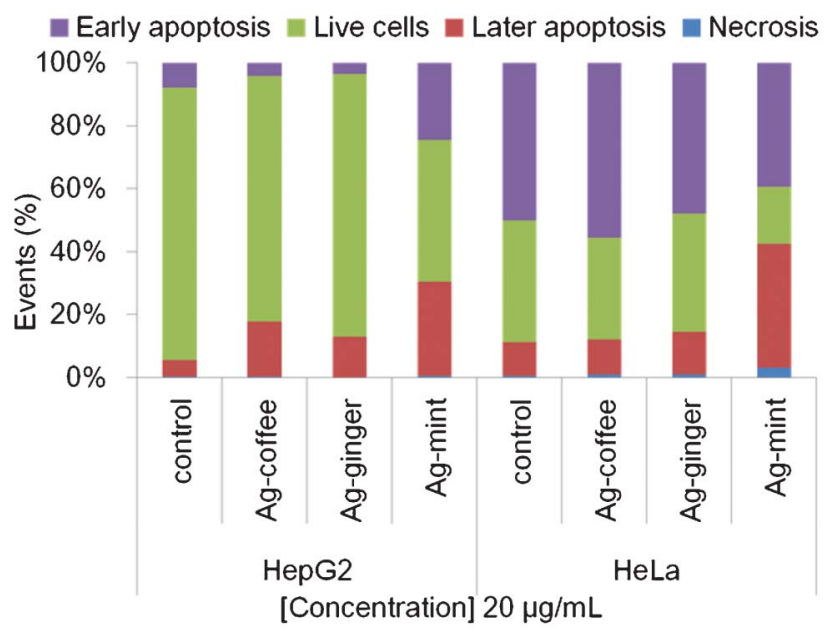

Fig. 8 Annexin-V staining of human cancer calls HepG2 and HeLa treated with $20 \mu \mathrm{gL}^{-1} \mathrm{Ag} \mathrm{NPs}$ for $24 \mathrm{~h}$ to detect the mode of cell death. The percentage of cells stained with PI alone represents necrotic cells, whereas the percentage of cells stained with FITC alone represents early apoptosis. Cells in the final stages of apoptosis take up both stains.

the viability of the cells by decreasing the $\mathrm{H}_{2} \mathrm{O}_{2}$-induced intracellular ROS level. ${ }^{74}$ However, ROS is also a normal product of cellular metabolism, which is an indispensible component in cell signaling and homeostasis. ${ }^{75}$ The cell signaling pathways can be disturbed at low levels of ROS, which in turn cause cell damage and ultimately cell death. ${ }^{75}$ In our study, the ROS level decreased drastically when cells were treated with all three Ag NPs, especially for Ag-ginger and Agmint NPs. The viability data is consistent with the decreased ROS levels in the cells, which is attributed to the antioxidant effect of the capping agents.

\section{Apoptosis and necrosis}

Apoptosis and necrosis, the most preferred responses for cell death among various mechanisms, ${ }^{33,76}$ were investigated to access the extent and mode of cell death upon exposure to $\mathrm{Ag}$ NPs. Annexin-V FITC was used as a marker for apoptosis while PI was utilized to detect plasma membrane integrity to recognize necrotic cell death. Statistical data were acquired from dot plots (Fig. S3 and S4, ESI $\dagger$ ), based on the percentages of unstained cells (viable cells), and those stained with PI (necrotic cells), FITC (apoptotic cells), and dual stained cells (late apoptosis). The results are shown in Fig. 8.

For Ag-ginger and Ag-coffee NPs treated HepG2 cells, a decrease in the percentage of viable cells $(3-8 \%)$ and early apoptosis cells $(3-4 \%)$ was observed as compared to control cells (Fig. 8). Moreover, a $7-12 \%$ increase was found in the percentage of later apoptosis cells, indicating that Ag-ginger and $\mathrm{Ag}$-coffee NPs were only slightly toxic to HepG2 cells at a concentration of $20 \mu \mathrm{g} \mathrm{mL}^{-1}$. However, a significant decrease in the percentage of live cells (42\%) was observed for $\mathrm{Ag}$-mint NPs treated cells, accompanied by an increase in both early apoptosis (17\%) and later apoptosis (25\%) stages. This confirmed that $\mathrm{Ag}$-mint NPs are the most toxic, which is consistent with cell viability results. 
The response of HeLa cells to Ag NPs was quite similar to that for HepG2 cells. A decrease of the percentage of live cells along with an increase in the percentage of later apoptosis cells was observed for HeLa cells treated with all three Ag NPs. Only small changes were observed on both Ag-ginger and Agcoffee NPs treated cells, which indicates that these two NPs were less toxic at low concentrations. However, around 30\% increase in later apoptosis cells along with a $20 \%$ decrease in live cells was observed for Ag-mint NPs treated cells, which indicates that $\mathrm{Ag}$-mint NPs were toxic to cells even at a low concentration. Moreover, no significant increase of necrotic cells was observed in both cell lines. Necrosis is usually related to loss of the lysosomal membrane integrity and uncontrolled release of inflammatory cellular contents, ${ }^{77}$ while apoptosis is associated with the generation of ROS and JNK activation, ${ }^{78}$ mitochondrial fusion/fission machinery, ${ }^{79}$ caspase activation, ${ }^{80}$ calcium $^{\text {overload }^{81}}$ or caused by death-inducing signals. ${ }^{82}$ Oh et al. ${ }^{33}$ reported that the apoptosis and necrosis observed among silica-titania hollow nanoparticles internalized macrophages were size-dependent and surface functionality-dependent, which agrees with other experimental results. ${ }^{71}$ Small changes in particle size and functional groups on the surface affect the mechanism of cell death. Furthermore, these factors may also have significant influence on the nanoparticle and membrane interaction, nanoparticle internalization and degradation within cells.

\section{Effect of Ag NPs on cell cycle}

Earlier reports have emphasized a bidirectional effect of ROS on genomic stability. ${ }^{83}$ High intracellular ROS levels in CTABcoated Au nanorods treated cells induced mitochondrial damage which led to changes in the cell cycle and increased apoptosis. ${ }^{32}$ Intracellular ROS levels can be decreased dramatically by the addition of a high dose of antioxidants. Furthermore, DNA damage from low level ROS in stem cells treated with antioxidants was reported to be concentration dependent. ${ }^{83}$ Moreover, the early effect of DNA damage was seen in the cell cycle progression. Cells with damaged DNA accumulated in the gap 1 (G1), DNA synthesis (S), or in gap 2/ mitosis (G2/M) phase while cells with irreversible damage accumulated in the sub G1 phase. ${ }^{84}$ By detecting parameters such as apoptosis, cell cycle arrest and evidence of DNA damage, the toxicity of Ag NPs to the cells is established.

The influence of Ag NPs on the percentage of cells in each phase of the cell cycle was analyzed (Fig. 9). Both the HeLa and HepG2 cell lines showed a decrease in the G1 phase, followed by a $\mathrm{G} 2 / \mathrm{M}$ arrest, except $\mathrm{Ag}-\mathrm{mint}$ treated HeLa cells which showed a decrease in the G2/M stage and significant increase in the sub G1 stage. There was an increase in sub G1 stage for $\mathrm{Ag}$-mint treated cells, which indicated that the cells were seriously damaged as a result of irreversible DNA damage. Thus, Ag-mint treated cells showed damage through both apoptosis and G2/M arrest. Only small increases in the sub G1 stage of HepG2 cells with $\mathrm{Ag}$-ginger and $\mathrm{Ag}$-coffee treatment were observed while no changes were found in HeLa cells. The proportion of cells in the $\mathrm{S}$ phase was less affected as compared to the G2/M population. The absence of changes in the number of cells in sub G1 for HeLa cells indicates that no significant cell death via apoptosis occurred when cells

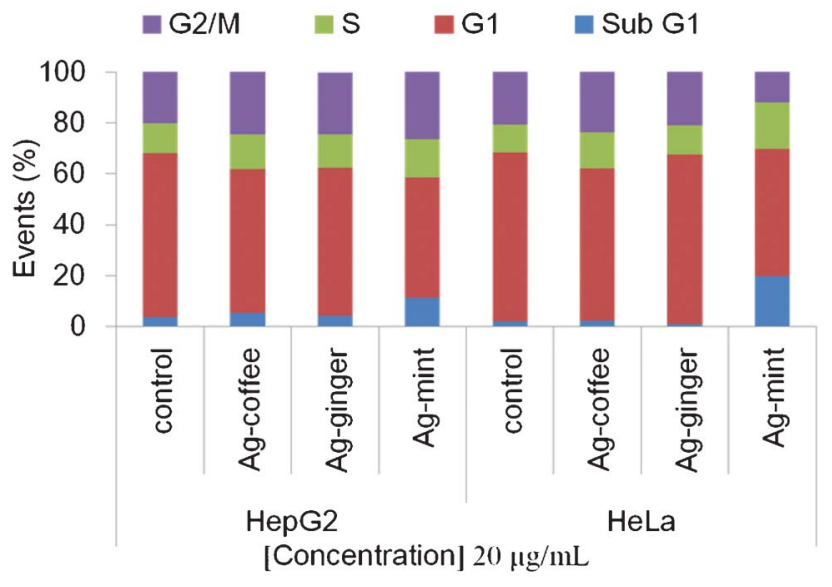

Fig. 9 Cell cycle data for HeLa and HepG2 treated with $20 \mu \mathrm{g} \mathrm{mL}^{-1}$ Ag NPs for $24 \mathrm{~h}$ to detect the DNA damage of the cells. Markers were set at regions of interest (sub G1, G1, S, and G2/M), and the percentage of cells (events) under each area was generated using Summit V4.3.02 software. Histograms are included in Fig. S5, ESI.†

were treated with Ag-ginger or Ag-coffee NPs. In other words, both Ag-ginger and $\mathrm{Ag}$-coffee treated cells only showed reversible DNA damage with $\mathrm{G} 2 / \mathrm{M}$ arrest.

Several reports suggest that Ag NPs could induce cell cycle arrest in the G2/M phase and enhance apoptosis. ${ }^{20,85,86}$ The absence of a large amount of apoptosis and necrosis for $\mathrm{Ag}$ ginger and $\mathrm{Ag}$-coffee NPs treated cells accompanied by $\mathrm{G} 2 / \mathrm{M}$ arrest (Fig. 9) indicates retarded cell proliferation, allowing cells extra time to repair DNA damage prior to segregation of chromosomes. However, the DNA repair could be affected by the reduction of the ATP content (Fig. 6) after Ag NPs treatment, as ATP plays multiple roles in the repair of DNA damage. ${ }^{87-89}$ Excessive ROS production has been reported to be harmful to DNA, while low levels of ROS affect cell signaling particularly at the level of redox modulation. ${ }^{90}$ Relatively low levels of ROS have been observed to promote cell proliferation rather than cell degeneration or death. ${ }^{74,91}$ Low levels of ROS have also been reported to induce DNA damage in cells ${ }^{83}$ and similar results were observed in our study.

\section{Conclusion}

In this study, a green synthesis of Ag NPs using mint, ginger, and coffee extracts as reducing and capping agents was developed. The cellular uptake and toxicity of Ag NPs was determined using the changes in cell morphology, cell viability and oxidative stress. Ag-mint, Ag-ginger and Ag-coffee NPs were found to be more toxic to HepG2 than to HeLa cells. Among all the Ag NPs, Ag-mint were the most toxic, followed by $\mathrm{Ag}$-ginger and $\mathrm{Ag}$-coffee were the least toxic. Morphology changes and cellular uptake observed among Ag NPs treated cells were considered as the first indication of toxicity. A significant decrease in cell viability was observed as a result of reduction in ATP. Surprisingly, bioextracts capped Ag NPs did not increase but decreased the production of ROS in a dose 
dependent manner, which can be attributed to the antioxidant activity of biomaterial extracts on the surface. The low levels of ROS are believed to be the trigger for DNA damage. No large amount of apoptosis or necrosis and G2/M arrested cells were observed for the cells exposed to Ag-ginger and Ag-coffee NPs, suggesting an active DNA repair pathway operating inside the damaged cells. On the other hand, a significant increase in apoptosis and arrest in the sub G1 stage was observed for Agmint NPs treated cells, indicating irreversible DNA damage. The higher toxicity of Ag-mint NPs to cancer cells could be further explored for evaluating their potential use in cancer therapy.

In summary, the results indicate that the cytotoxicity of $\mathrm{Ag}$ NPs was strongly related to their compositions and capping agents. Among the three Ag NPs investigated, Ag-mint NPs were much more toxic compared to $\mathrm{Ag}$-ginger and $\mathrm{Ag}$-coffee NPs. Exposure of cells to Ag NPs led to low levels of ROS which caused DNA damage followed by cell arrest in the G2/M stage and eventually cell death through apoptosis. However, complete elimination of toxicity, especially at higher concentrations, has not yet been achieved and needs further studies.

\section{Acknowledgements}

The authors acknowledge technical support from Department of Chemistry and Department of Biological Science, National University of Singapore. WC also would like to thank the National University of Singapore for a PhD scholarship.

\section{References}

1 B. Van de Broek, N. Devoogdt, A. D’Hollander, H. L. Gijs, K. Jans, L. Lagae, S. Muyldermans, G. Maes and G. Borghs, ACS Nano, 2011, 5, 4319-4328.

2 A. Riedinger, M. P. Leal, S. R. Deka, C. George, I. R. Franchini, A. Falqui, R. Cingolani and T. Pellegrino, Nano Lett., 2011, 11, 3136-3141.

3 R. Chen, T. A. Ratnikova, M. B. Stone, S. Lin, M. Lard, G. Huang, J. S. Hudson and P. C. Ke, Small, 2010, 6, 612-617.

4 Y. Y. Tsai, Y. H. Huang, Y. L. Chao, K. Y. Hu, L. T. Chin, S. H. Chou, A. L. Hour, Y. D. Yao, C. S. Tu, Y. J. Liang, C. Y. Tsai, H. Y. Wu, S. W. Tan and H. M. Chen, ACS Nano, 2011, 5, 9354-9369.

5 F. Zhao, Y. Zhao, Y. Liu, X. L. Chang, C. Y. Chen and Y. L. Zhao, Small, 2011, 7, 1322-1337.

6 Q. A. Pankhurst, N. T. K. Thanh, S. K. Jones and J. Dobson, J. Phys. D: Appl. Phys., 2009, 42.

7 M. Moros, B. Hernáez, E. Garet, J. T. Dias, B. Sáez, V. Grazú, Á. González-Fernández, C. Alonso and J. M. de la Fuente, ACS Nano, 2012, 6, 1565-1577.

8 J. Cheng, K. A. S. Fernando, L. M. Veca, Y.-P. Sun, A. I. Lamond, Y. W. Lam and S. H. Cheng, ACS Nano, 2008, 2, 2085-2094.

9 E. Oh, J. B. Delehanty, K. E. Sapsford, K. Susumu, R. Goswami, J. B. Blanco-Canosa, P. E. Dawson,
J. Granek, M. Shoff, Q. Zhang, P. L. Goering, A. Huston and I. L. Medintz, ACS Nano, 2011, 5, 6434-6448.

10 H. Yuan, A. M. Fales and T. Vo-Dinh, J. Am. Chem. Soc., 2012, 134, 11358-11361.

11 J. L. Perry, K. G. Reuter, M. P. Kai, K. P. Herlihy, S. W. Jones, J. C. Luft, M. Napier, J. E. Bear and J. M. DeSimone, Nano Lett., 2012, 12, 5304-5310.

12 N. Vigneshwaran, R. P. Nachane, R. H. Balasubramanya and P. V. Varadarajan, Carbohydr. Res., 2006, 341, 2012-2018.

13 A. D. Dwivedi and K. Gopal, Colloids Surf., A, 2010, 369, 27-33.

14 D. Philip, Spectrochim. Acta, Part A, 2009, 73, 650-653.

15 D. Philip, Spectrochim. Acta, Part A, 2010, 75, 1078-1081.

16 P. Vasileva, B. Donkova, I. Karadjova and C. Dushkin, Colloids Surf., A, 2011, 382, 203-210.

17 R. Venu, T. S. Ramulu, S. Anandakumar, V. S. Rani and C. G. Kim, Colloids Surf., A, 2011, 384, 733-738.

18 U. Samuel and J. P. Guggenbichler, Int. J. Antimicrob. Agents, 2004, 23, S75-S78.

19 J. Chen, C. Han, X. Lin, Z. Tang and S. Su, Zhonghua Waike Zazhi, 2006, 50-53.

20 P. V. AshaRani, G. L. K. Mun, M. P. Hande and S. Valiyaveettil, ACS Nano, 2009, 3, 279-290.

21 M. C. Moulton, L. K. Braydich-Stolle, M. N. Nadagouda, S. Kunzelman, S. M. Hussain and R. S. Varma, Nanoscale, 2010, 2, 763-770.

22 K. P. Kumar, W. Paul and C. P. Sharma, Process Biochem., 2011, 46, 2007-2013.

23 M. N. Nadagouda and R. S. Varma, Green Chem., 2008, 10, 859-862.

24 H. Bar, D. K. Bhui, G. P. Sahoo, P. Sarkar, S. P. De and A. Misra, Colloids Surf., A, 2009, 339, 134-139.

25 S. P. Dubey, M. Lahtinen and M. Sillanpää, Colloids Surf., A, 2010, 364, 34-41.

26 S. P. Dubey, M. Lahtinen and M. Sillanpää, Process Biochem., 2010, 45, 1065-1071.

27 P. Kouvaris, A. Delimitis, V. Zaspalis, D. Papadopoulos, S. A. Tsipas and N. Michailidis, Mater. Lett., 2012, 76, 18-20.

28 M. N. Ghayur, A. H. Gilani, M. B. Afridi and P. J. Houghton, Vasc. Pharmacol., 2005, 43, 234-241.

29 G. C. Jagetia and M. S. Baliga, Strahlenther. Onkol., 2002, 178, 91-98.

30 H. Vallhov, J. Qin, S. M. Johansson, N. Ahlborg, M. A. Muhammed, A. Scheynius and S. Gabrielsson, Nano Lett., 2006, 6, 1682-1686.

31 P. W. Wang, S. M. Henning and D. Heber, PLoS One, 2010, 5.

32 Y. Qiu, Y. Liu, L. M. Wang, L. G. Xu, R. Bai, Y. L. Ji, X. C. Wu, Y. L. Zhao, Y. F. Li and C. Y. Chen, Biomaterials, 2010, 31, 7606-7619.

33 W. K. Oh, S. Kim, M. Choi, C. Kim, Y. S. Jeong, B. R. Cho, J. S. Hahn and J. Jang, ACS Nano, 2010, 4, 5301-5313.

34 S. M. Hussain, K. L. Hess, J. M. Gearhart, K. T. Geiss and J. J. Schlager, Toxicol. in Vitro, 2005, 19, 975-983.

35 L. Goya, C. Delgado-Andrade, J. A. Rufian-Henares, L. Bravo and F. J. Morales, Mol. Nutr. Food Res., 2007, 51, 536-545.

36 B. H. Ali, G. Blunden, M. O. Tanira and A. Nemmar, Food Chem. Toxicol., 2008, 46, 409-420.

37 A. A. Shati and F. G. Elsaid, Food Chem. Toxicol., 2009, 47, 1945-1949. 
38 Y. Shukla and M. Singh, Food Chem. Toxicol., 2007, 45, 683-690.

39 R. S. Policegoudra, K. Abiraj, D. C. Gowda and S. M. Aradhya, J. Chromatogr., B: Anal. Technol. Biomed. Life Sci., 2007, 852, 40-48.

40 N. Sazhina, V. Misin and E. Korotkova, Chemistry \& Chemical Technology, 2011, 5, 13-17.

41 H. G. Grigoleit and P. Grigoleit, Phytomedicine, 2005, 12, 612-616.

42 J. H. Gao and B. Xu, Nano Today, 2009, 4, 37-51.

43 I. Rahath Kubra, K. Ramalakshmi and L. J. M. Rao, E-J. Chem., 2011, 8, 721-726.

44 G. M. She, C. Xu, B. Liu and R. B. Shi, J. Food Sci., 2010, 75, C359-C362.

45 M. D. del Castillo, J. M. Ames and M. H. Gordon, J. Agric. Food Chem., 2002, 50, 3698-3703.

46 A. Shirin and J. Prakash, Health \& Environmental Research Online, 2010, 4, 2674-2679.

47 Z. Shervani, Y. Ikushima, M. Sato, H. Kawanami, Y. Hakuta, T. Yokoyama, T. Nagase, H. Kuneida and K. Aramaki, Colloid Polym. Sci., 2008, 286, 403-410.

48 D. Seo, J. C. Park and H. Song, J. Am. Chem. Soc., 2006, 128, 14863-14870.

49 B. M. Barth, R. Sharma, E. I. Altinoglu, T. T. Morgan, S. S. Shanmugavelandy, J. M. Kaiser, C. McGovern, G. L. Matters, J. P. Smith, M. Kester and J. H. Adair, ACS Nano, 2010, 4, 1279-1287.

50 T. Komatsu, M. Tabata, M. Kubo-Irie, T. Shimizu, K. Suzuki, Y. Nihei and K. Takeda, Toxicol. in Vitro, 2008, 22, 1825-1831.

51 S. Zhang, J. Li, G. Lykotrafitis, G. Bao and S. Suresh, Adv. Mater., 2009, 21, 419-424.

52 R. Hu, K.-T. Yong, I. Roy, H. Ding, S. He and P. N. Prasad, J. Phys. Chem. C, 2009, 113, 2676-2684.

53 H. Ding, K.-T. Yong, I. Roy, H. E. Pudavar, W. C. Law, E. J. Bergey and P. N. Prasad, J. Phys. Chem. C, 2007, 111, 12552-12557.

54 Y. Teow and S. Valiyaveettil, Nanoscale, 2010, 2, 2607-2613.

55 W. Qian, X. Huang, B. Kang and M. A. El-Sayed, J. Biomed. Opt., 2010, 15, 046025-046025.

56 T. dos Santos, J. Varela, I. Lynch, A. Salvati and K. A. Dawson, Small, 2011, 7, 3341-3349.

57 H. Mueller, M. U. Kassack and M. Wiese, J. Biomol. Screening, 2004, 9, 506-515.

58 T. Xia, M. Kovochich, J. Brant, M. Hotze, J. Sempf, T. Oberley, C. Sioutas, J. I. Yeh, M. R. Wiesner and A. E. Nel, Nano Lett., 2006, 6, 1794-1807.

59 Y. Y. Zhang, L. Hu, D. H. Yu and C. Y. Gao, Biomaterials, 2010, 31, 8465-8474.

60 B. Fuhrman, M. Rosenblat, T. Hayek, R. Coleman and M. Aviram, J. Nutr., 2000, 130, 1124-1131.

61 E. W. C. Chan, Y. Y. Lim, K. L. Chong, J. B. L. Tan and S. K. Wong, J. Food Compos. Anal., 2010, 23, 185-189.

62 Nestlé, NESCAFÉ GOLD Rich Roast, http:/www.nestle. com.au/Products/Categories/Hot-Cold-Beverages/Coffee/ Nescafe/Soluble/Rich-Roast.

63 P. P. Almeida, N. Mezzomo and S. R. S. Ferreira, Food Bioprocess Technol., 2012, 5, 548-559.

64 T. P. Krishnakantha and B. R. Lokesh, Indian J. Biochem. Biophys., 1993, 30, 133-134.
65 A. Chompoosor, K. Saha, P. S. Ghosh, D. J. Macarthy, O. R. Miranda, Z.-J. Zhu, K. F. Arcaro and V. M. Rotello, Small, 2010, 6, 2246-2249.

66 R. Foldbjerg, P. Olesen, M. Hougaard, D. A. Dang, H. J. Hoffmann and H. Autrup, Toxicol. Lett., 2009, 190, 156-162.

67 P. Sanpui, A. Chattopadhyay and S. S. Ghosh, ACS Appl. Mater. Interfaces, 2011, 3, 218-228.

68 M. J. Piao, K. A. Kang, I. K. Lee, H. S. Kim, S. Kim, J. Y. Choi, J. Choi and J. W. Hyun, Toxicol. Lett., 2011, 201, 92-100.

69 W. He, Y.-T. Zhou, W. G. Wamer, M. D. Boudreau and J.J. Yin, Biomaterials, 2012, 33, 7547-7555.

70 Y. Jin, S. Lohstreter and J. X. Zhao, in Nanotechnologies for the Life Sciences, ed. C. S. S. R. Kumar, Wiley-VCH Verlag GmbH \& Co. KGaA, Weinheim, Editon edn., 2007, vol. 2, pp. 221-244.

71 Y. Pan, S. Neuss, A. Leifert, M. Fischler, F. Wen, U. Simon, G. Schmid, W. Brandau and W. Jahnen-Dechent, Small, 2007, 3, 1941-1949.

72 A. L. Levonen, R. P. Patel, P. Brookes, Y. M. Go, H. Jo, S. Parthasarathy, P. G. Anderson and V. M. Darley-Usmar, Antioxid. Redox Signaling, 2001, 3, 215-229.

73 P. M. Burch and N. H. Heintz, Antioxid. Redox Signaling, 2005, 7, 741-751.

74 L. B. Zhang, L. Laug, W. Munchgesang, E. Pippel, U. Gosele, M. Brandsch and M. Knez, Nano Lett., 2010, 10, 219-223.

75 W. C. Burhans and N. H. Heintz, Free Radical Biol. Med., 2009, 47, 1282-1293.

76 Y. Jin, S. Kannan, M. Wu and J. X. Zhao, Chem. Res. Toxicol., 2007, 20, 1126-1133.

77 S. L. Fink and B. T. Cookson, Infect. Immun., 2005, 73, 1907-1916.

78 Y. H. Hsin, C. F. Chena, S. Huang, T. S. Shih, P. S. Lai and P. J. Chueh, Toxicol. Lett., 2008, 179, 130-139.

79 A. Jahani-Asl, M. Germain and R. S. Slack, Biochim. Biophys. Acta, Mol. Basis Dis., 2010, 1802, 162-166.

80 E.-J. Park, J. Yi, K.-H. Chung, D.-Y. Ryu, J. Choi and K. Park, Toxicol. Lett., 2008, 180, 222-229.

81 T. Ozaki, T. Yamashita and S.-i. Ishiguro, Biochim. Biophys. Acta, Mol. Cell Res., 2009, 1793, 1848-1859.

82 J. E. Chipuk and D. R. Green, Nat. Rev. Mol. Cell Biol., 2005, 6, 268-275.

83 T.-S. Li and E. Marbán, Stem Cells, 2010, 28, 1178-1185.

84 K. Ishikawa, H. Ishii and T. Saito, DNA Cell Biol., 2006, 25, 406-411.

85 H.-J. Eom and J. Choi, Environ. Sci. Technol., 2010, 44, 8337-8342.

86 L. K. Liu, F. Ni, J. C. Zhang, X. L. Jiang, X. A. Lu, Z. R. Guo and R. Z. Xu, Acta Biochim. Biophys. Sin., 2011, 43, 316-323.

87 T. Costelloe, J. FitzGerald, N. J. Murphy, A. Flaus and N. F. Lowndes, Exp. Cell Res., 2006, 312, 2677-2686.

88 S. Seki, S. Mori, A. Nakashima and T. Oda, Carcinogenesis, 1987, 8, 1391-1394.

89 E. Citterio, V. Van Den Boom, G. Schnitzler, R. Kanaar, E. Bonte, R. E. Kingston, J. H. J. Hoeijmakers and W. Vermeulen, Mol. Cell. Biol., 2000, 20, 7643-7653.

90 K. R. Martin and J. C. Barrett, Hum. Exp. Toxicol., 2002, 21, 71-75.

91 T. Finkel, FEBS Lett., 2000, 476, 52-54. 